\title{
Prevalence of antibody to hepatitis $C$ virus in Saudi blood donors
}

\author{
BANDAR Al-KNAWy mBBS FRCPC, AWAD A El-MEKKI MBBS PHD, JAMAl HAMDI FRCS, RAJA THIGA MBBS MSC, \\ ANWAR SHEIKHA MBCHB MRCPATH
}

B Al-Knawy, AA El-MekKi, J Hamdi, R Thiga, A SheikHa. Prevalence of antibody to hepatitis C virus in Saudi blood donors. Can J Gastroenterol 1995;9(3):141-143. The prevalence of antibodies to hepatitis C virus (anti-HCV) was retrospectively determined using a second generation enzyme immunoassay in 3868 blood donors from the southern part of Saudi Arabia in an area with high prevalence of hepatitis B virus (HBV) infection. Of 3354 Saudis, 48 (1.43\%) were seropositive for anti-HCV. A high prevalence ( 43 of 204, 21.08\%) of anti-HCV was observed among Egyptian donors compared with Saudis (1.43\%) and other nationalities (eight of 310, 2.58\%). Furthermore, the prevalence of anti-HCV antibodies was observed to increase with age, peaking in the 25 to 34 year age group. From this and other studies conducted in different regions of Saudi Arabia, the prevalence of anti-HCV among Egyptian donors appears to range from 19.2 to $24.5 \%$, and among Saudi donors appears to range from 1.00 to $1.7 \%$, a rate similar to that reported from western countries; this latter rate does not seem to be influenced by the high prevalence of HBV infection in this region.

Key Words: Anti-hepatitis C virus, Blood donors, Saudi Arabia

\section{Prévalence de l'anticorps anti-virus de l'hépatite C chez des donneurs de sang saoudiens}

RÉSUMÉ : La prévalence des anticorps anti-virus de l'hépatite C (anti-VHC) a été identifiée rétrospectivement à l'aide d'un essai immunologique enzymatique de deuxième génération chez 3868 donneurs de sang provenant de la partie méridionale de l'Arabie Saoudite, dans une région où la prévalence de l'infection au virus de l'hépatite B (VHB) est élevée. Quarante-huit Saoudiens sur 3354 $(1,43 \%)$ se sont révélés séropositifs à l'égard de l'anti-VHC. Une prévalence élevée (43 sur 204, 21,08\%) des anticorps anti-VHC a été observée parmi des donneurs égyptiens en comparaison avec les Saoudiens $(1,43 \%)$ et autres nationalités ( 8 sur 310, 2,58\%). De plus, la prévalence des anticorps anti-VHC s'est révélée

voir page suivante

Departments of Medicine, Gastroenterology Unit, Clinical Microbiology and Parasitology, Surgery and Haematology, College of Medicine, King Saud University; and Department of Paediatrics, Asir Central Hospital, Abha, Kingdom of Saudi Arabia

Correspondence and reprints: Dr Bandar Al-Knawy, College of Medicine, King Saud University, PO Box 641, Abha, Saudi Arabia. Telephone 00-966-7-2260676,

Fax 00-996-7-2247570

Received for publication March 28, 1994. Accepted October 28, 1994
$\mathrm{H}$ EPATITIS C VIRUS (HCV) INFECTion accounted for about 70 to $90 \%$ of post-transfusion hepatitis before the recent introduction of mandatory testing of donated blood. The parenterally transmitted non-A, non-B hepatitis is caused, in the majority of cases, by a small single-stranded RNA virus closely related to flaviviruses, currently recognized as HCV.

The recent isolation of viral RNA from chimpanzees infected with hepatitis $\mathrm{C}$ led to the development of $\mathrm{HCV}$ testing using antibodies against recombinant antigens (1). The five antibody tests available include: ELISA I, which detects antibody against C-100-3; ELISA II, which detects antibodies against C-100-3, c-33c and c-22-3; recombinant immunoblot assay (RIBA) I, which detects antibodies against C100-3 and 5-1-1; RIBA II, which detects antibodies against C-100-3, 5-1-1, c$33 \mathrm{c}$ and $\mathrm{c}-22-3$; and RIBA III, which incorporates recombinant antigens derived from the NS5 region in addition to the antigenic components in RIBA II. Viral RNA is currently detected by polymerase chain reaction using CDNA primers from the highly conserved noncoding $5^{\prime}$ region of $\mathrm{HCV}$ genome (2).

The routine policy of HCV antibody testing has reduced the incidence of acute post-transfusion hepatitis. The current risk of post-transfusion in hepatitis is about three for every 10,000 
proportionnelle à l'âge, le maximum correspondant au groupe des 25 à 34 ans. À partir de cette étude, et d'autres menées dans différentes régions de l'Arabie Saoudite, la prévalence de l'anticorps anti-VHC parmi les donneurs égyptiens semble varier de 19,2 à 24,5\% et parmi les donneurs Saoudiens, semble varier de 1,0 à $1,7 \%$, soit un taux similaire à celui que l'on observe dans les pays occidentaux. Ce dernier taux ne semble pas être influencé par la prévalence élevée de l'infection au VHB dans cette région.

\begin{tabular}{|c|c|c|c|}
\hline $\begin{array}{l}\text { Age } \\
\text { group }\end{array}$ & Population & $\begin{array}{c}\text { Anti- } \\
\text { HCV (\%) }\end{array}$ & $\begin{array}{c}\text { HBsAg } \\
(\%)\end{array}$ \\
\hline $18-24$ & 1540 & 0.97 & 4.29 \\
\hline $25-34$ & 1427 & 0.26 & 6.50 \\
\hline $35-44$ & 748 & 5.21 & 6.68 \\
\hline $45+$ & 153 & 5.23 & 10.46 \\
\hline Total & 3868 & 2.56 & 5.82 \\
\hline
\end{tabular}

HBSAg Hepatitis B surface antigen; HCV Hepatitis $C$ virus

TABLE 2

Prevalence of antihepatitis $C$ virus antibody by nationality

\begin{tabular}{lcc}
\hline Nationality & $\begin{array}{c}\text { \# tested } \\
\text { (\% total) }\end{array}$ & $\begin{array}{c}\text { \# positive } \\
(\%)\end{array}$ \\
\hline Saudi & $3354(86.71)$ & $48(1.43)$ \\
Egyptians & $204(5.27)$ & $43(21.08)$ \\
Others & $310(8.02)$ & $8(2.58)$ \\
Total & $3868(100)$ & $99(2.56)$ \\
\hline
\end{tabular}

units transfused, $0.75 \% /$ patient (3). The development of chronic liver disease following $\mathrm{HCV}$ infection is the highest among other viral causes of hepatitis. Chronic hepatitis develops in $62 \%$ of acute community-acquired hepatitis $\mathrm{C}$ cases and cirrhosis develops in 10 to $20 \%(4-6)$.

The prevalence of HCV antibodies in blood donors varies in different parts of the world: Germany, 0.24 to $0.79 \%$ (7); England, 0.5 to $1 \%$ (8); Italy, $0.87 \%$ (9); Spain; 1.2\% (10); Japan $1.12 \%$ (11); and South Africa, 0.6 to $1.2 \%$ (12). In the Kingdom of Saudi Arabia, the prevalence of hepatitis C antibody among blood donors from the central part of Saudi Arabia is 1.00 to $1.24 \%(13,14)$. A prevalence of $1.7 \%$ has recently been reported in the Jeddah area among Saudi blood donors (13). The aim of this study was to determine the prevalence of $\mathrm{HCV}$ anti-
TABLE 3

Prevalence of antihepatitis $C$ virus among positive Saudi blood donors by age group

\begin{tabular}{lc}
\hline $\begin{array}{l}\text { Age } \\
\text { group }\end{array}$ & $\begin{array}{c}\text { Number positive } \\
\text { (\% of total positives) }\end{array}$ \\
\hline $18-24$ & $14(29.2 \%)$ \\
$25-34$ & $19(39.6 \%)$ \\
$35-44$ & $11(23.0 \%)$ \\
$45+$ & $4(8.2 \%)$ \\
Total & $48(100 \%)$ \\
\hline
\end{tabular}

body in the southern part of Saudi Arabia, an area with the highest carrier rate of hepatitis B virus (HBV) (10\%) and whether the prevalence of HCV antibodies was influenced by the higher prevalence of HBV infection.

\section{MATERIAL AND METHODS}

This study was conducted in Asir Central Hospital, the only centre in the region where $\mathrm{HCV}$ antibody testing is available. The authors retrospectively examined the blood bank records for a period of one year. All blood donors were unpaid male volunteers who appeared clinically healthy and gave no history of any predisposing risk factors to HCV infection such as use of intravenous drugs, homosexuality, previous history of blood transfusion, etc. Liver function tests were not performed. Donated blood units from 3868 individuals - 3354 Saudis (86.71\%), 204 Egyptians (5.27\%) and 310 other nationalities $(8.02 \%)$ - were investigated. Each unit was tested for hepatitis B surface antigen (HBSAG) (Pasteur's kit, Sanofi Diagnostics Pasteur, Marnes La Coquette, France) and HCV antibody enzyme immunoassay II (Pasteur's kit), which detects antibodies to three different regions of $\mathrm{HCV}$ : C-100-3, c-33c and c-22-3. If the unit repeatedly tested positive, however, no supplementary tests for anti-HCV were done. Blood units were also tested for human immunodeficiency virus (HIV) (Pasteur's kit), venereal disease and malaria. All assays were performed and evaluated according to the manufacturers' instructions.

\section{RESULTS}

The overall prevalence of anti-HCV antibodies and HBSAG among the different age groups in the population studied is shown in Table 1. Generally, seropositivity to $\mathrm{HCV}$ appears to increase with age. The prevalence rate of positive anti-HCV test by nationality (Table 2) is as follows: Saudis, 1.43\%; Egyptians, $21.08 \%$; other nationalities, 2.58\%. Among the anti-HCV-positive Saudi nationals (Table 3), the peak of seropositivity $(39.6 \%)$ seems to lie within the 25 to 34 year age group and subsequently declines to $8.2 \%$ in the 45 years and older age group. In the Saudi donor population studied, the prevalence of HBSAG is $4.0 \%$ (data not shown). Only one Saudi and one Egyptian were positive for both HBSAG and anti-HCV and none was HIV-positive. Donors with positive anti-HCV tests were not further evaluated to assess their liver disease status.

\section{DISCUSSION}

It has been a general policy in most, if not all, of the Saudi Arabian blood banks to screen for HCV antibody. In this study, we assessed the prevalence of HCV antibodies in apparently healthy male Saudi blood donors in southern Saudi Arabia; it was $1.43 \%$, a figure similar to those obtained from other parts of Saudi Arabia, where the prevalence of HBV infection is relatively low. The high prevalence of HBV infection $(10 \%)$ in the population did not seem to influence the prevalence of anti-HCV antibodies, which was found to be less that half that of HBSAG ( $1.43 \%$ versus $4.0 \%$ ). (The data in Table 1 may not reflect the actual situation regarding HBV infection among Saudis since those younger than 18 years were not included in the study, in addition to the mixed nature of the population.) There were only two individuals (a Saudi and an Egyptian) who 
were co-infected with HCV and HBV. These data confirm the studies by Hyams et al (15), who showed that the epidemiology of HCV differs significantly from that of HBV. It appears that these donors had the sporadic type of HCV virus infection and that their exposure to HCV seemed to increase with age, peaking in the 25 to 34 year age group. The decline in the prevalence of these antibodies in the older age group (Table 3) may only reflect the rela-

\section{REFERENCES}

1. Choo QL, Kuo G, Weiner AJ, Overby LR, Bradley W, Houghton M. Isolation of a cDNA clone derived from a blood-borne non-A, non-B viral hepatitis genome. Science 1989;224:362.

2. Kuo G, Choo QL, Alter HJ, et al. An assay for circulating antibodies to a major aetiologic virus of human non-A, non-B hepatitis. Science 1989;244:362.

3. Donaheu JG, Munoz A, Ness PM, et al. The declining risk of post-transfusion hepatitis $C$ virus infection. N Engl J Med 1992;327:369-73.

4. Alter MJ. The natural history of community acquired hepatitis $\mathrm{C}$ in United States. N Engl J Med 1992;327:1899-905.

5. Koretz RL, Stone O, Mousa M, Gitnick GL. NANB post-transfusion hepatitis, a decade later. Gastroenterology 1985;88:1251-4.

6. Alter HJ. The consequences of non A, non B hepatitis. In: Seef LB, Lewis JH, eds. Current Perspective in Hepatology. New York: Plenum Medical Books, 1989:83-97.

7. Kuhnl P, Seidl S, Stangel H, et al. Antibody to hepatitis $\mathrm{C}$ virus in German blood donors. Lancet 1989;ii:324.

8. Contreras M, Barbara JAJ. Screening for hepatitis $\mathrm{C}$ virus antibody. Lancet 1989;ii:505.

9. Sirchia G, Almini D, Bellobouono A, et al. Antibodies to hepatitis $\mathrm{C}$ virus in tively small number of donors in this age group. Therefore the prevalence of HCV seropositivity in Saudi Arabian blood donors seems to range from 1.00 to $1.70 \%$, a rate similar to that reported from western countries.

In the present study we have shown a high prevalence of anti-HCV among Egyptian blood donors. This has also been observed in other parts of the Kingdom (16). Studies from Al-Baha have shown a prevalence of $22.7 \%$

Italian blood donors. Vox Sang 1990;59:26-9.

10. Esteban JI, Esteban VC, LopezTalavera J, et al. Epidemiology of hepatitis $\mathrm{C}$ virus infection. In: Hollinger FB, Lemoon SM, Margolis $\mathrm{H}$, eds. Viral Hepatitis and Liver Disease. Philadelphia: Williams \& Wilkins, 1992:413-5.

11. Tango T, Minegishi K, Mitsumori T, et al. Specificity and sensitivity of HCV antibody test in non-A, non-B hepatitis. Nihon Rinsho 1990;48:33-8.

12. Ellis LA, Brown D, Conradie JD, et al. Regional prevalence of hepatitis C antibodies in South Africa: an analysis of fresh and stored serum. In: Hollinger FB, Lemoon SM, Margolis H, eds. Viral Hepatitis and Liver Disease. Philadelphia: Williams \& Wilkins, 1992:445-7.

13. Bernvil SS, Andrew VJ, Karim A. Hepatitis C antibody prevalence in Saudi Arabian blood donors population. Ann Saudi Med 1991;2:563.

14. Facharzt MA, Facunle YM, El-Karamani WM, et al. Prevalence of antibodies to hepatitis $\mathrm{C}$ virus in blood donors in Riyadh. Ann Saudi Med 1991;2:501.

15. Hyams KC, Phillips LA, Moran AY, Tjeda A, Wignall FS, Escamillia J. Seroprevalence of hepatitis C antibody in Peru. J Med Virol 1992;37:127-31.

16. Saeed AA, Al-Admawa AM, Al-Rasheed A, et al. Hepatitis C virus infection in Egyptian volunteer blood (personal communication). A higher figure $(24.5 \%)$ has also been reported (17) among Egyptian blood donors from Jeddah. Furthermore, Egyptian volunteer blood donors in Riyadh had an anti-HCV positivity rate of $19.2 \%$ compared with Sudanese (1.9\%) and Yemenis (2.4\%) donors (9). The reason for the high prevalence of anti-HCV positivity among Egyptians is not clear and needs further investigations.

donors in Riyadh. Lancet 1991;338:459-60.

17. Abdelaal M, Rowbottom D, Zawawi T, et al. Epidemiology of hepatitis $C$ virus: a study of male blood donors in Saudi Arabia. Transfusion 1994;34:135-7. 


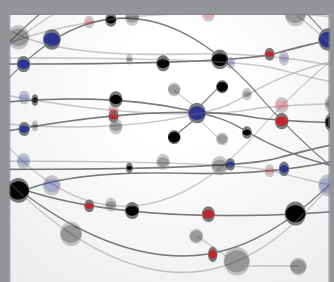

The Scientific World Journal
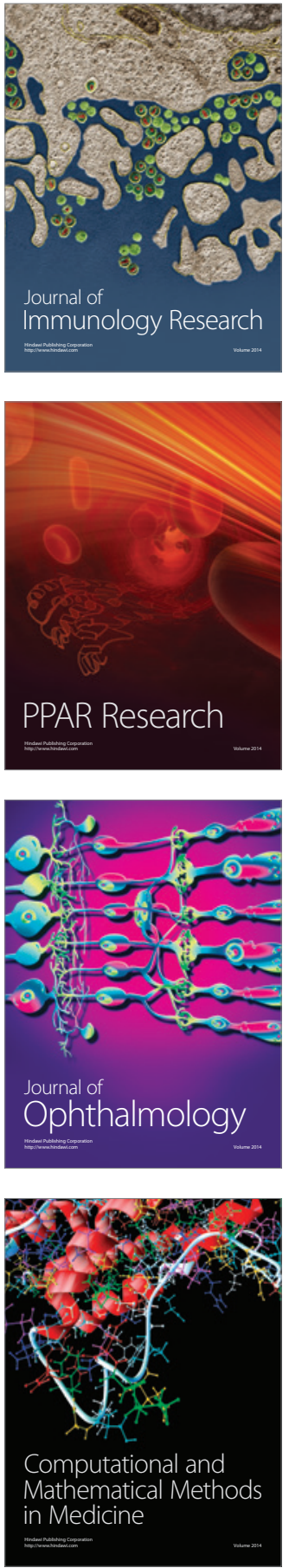

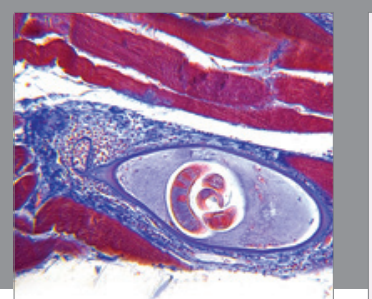

Gastroenterology Research and Practice

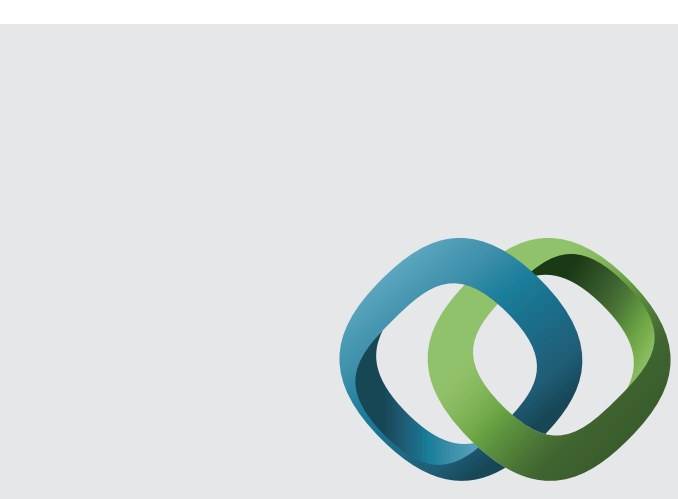

\section{Hindawi}

Submit your manuscripts at

http://www.hindawi.com
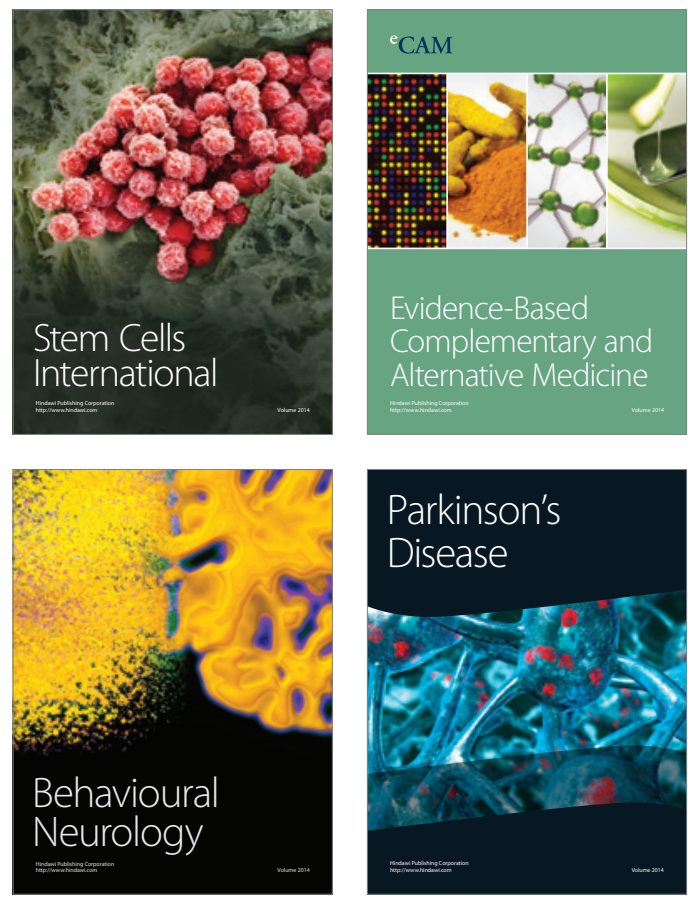
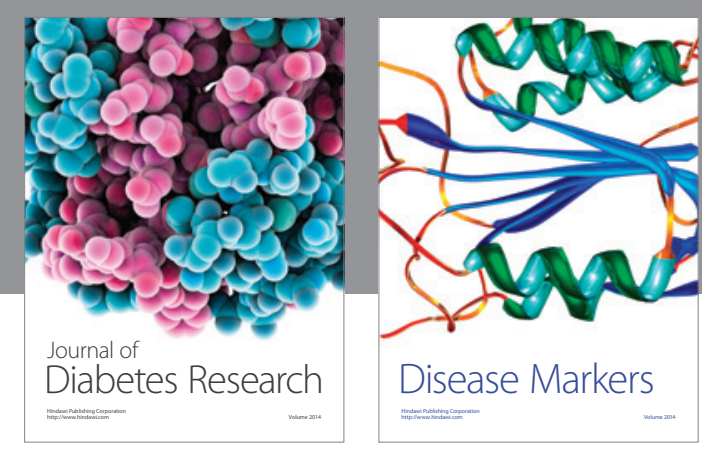

Disease Markers
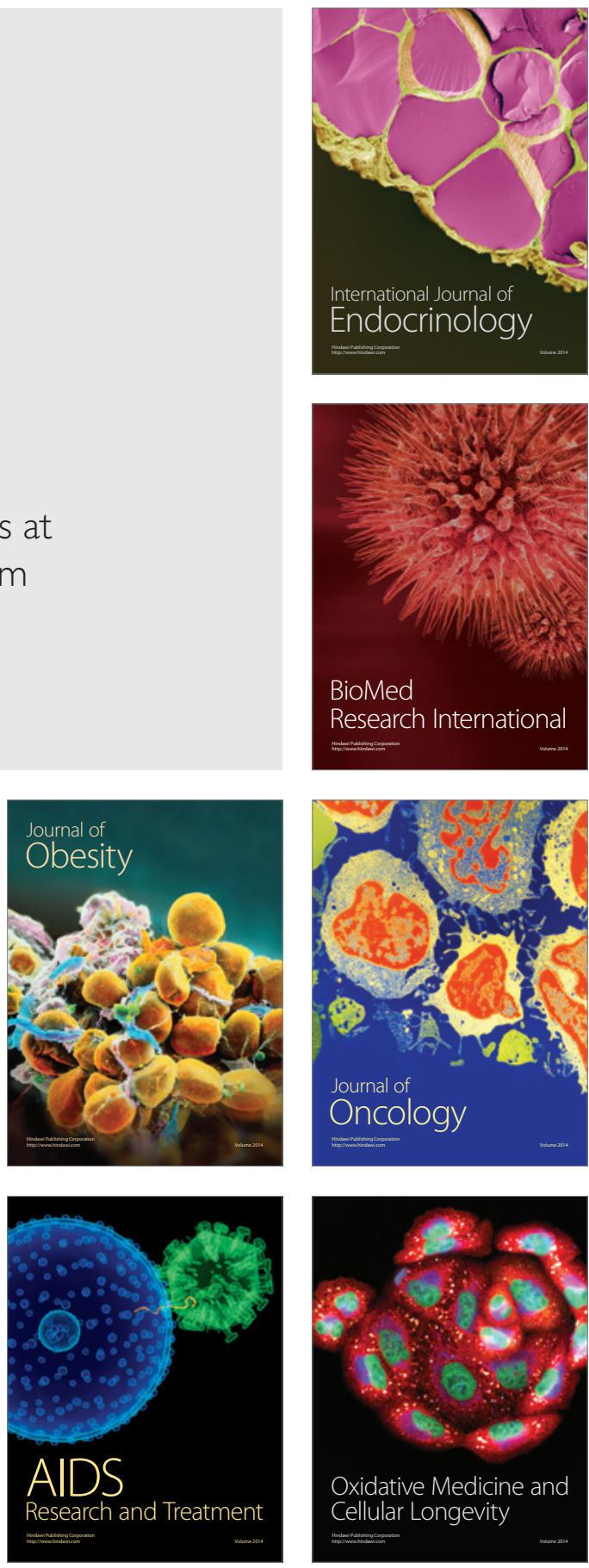